\title{
Polyisoprenoid Profiling of Mangrove Litters-based Zonations and Salinity Groups in North Sumatra, Indonesia
}

\author{
Mohammad Basyuni a,b,*, Rahmah Hayati ${ }^{\text {b }}$, Arif Nuryawan ${ }^{\mathrm{a}, \mathrm{b}}$, Etti Sartina Siregar ${ }^{\mathrm{a}, \mathrm{c}}$, \\ Sumaiyah Sumaiyah $^{\mathrm{d}}$, Tadashi Kajita ${ }^{\mathrm{e}}$ \\ ${ }^{a}$ Center of Excellence for Mangrove, Universitas Sumatera Utara, Medan, 20155, Indonesia \\ ${ }^{b}$ Department of Forestry, Faculty of Forestry, Universitas Sumatera Utara, Medan, 20155, Indonesia \\ ${ }^{c}$ Department of Biology, Faculty of Mathematics and Natural Sciences, Universitas Sumatera Utara, Medan, 20155, Indonesia \\ ${ }^{d}$ Department of Technology Pharmacy, Faculty of Pharmacy, Universitas Sumatera Utara, Medan, 20155, Indonesia \\ e Iriomote Station, Tropical Biosphere Research Center, University of the Ryukyus, Taketomi, Okinawa, 907-1541, Japan
}

Corresponding author: *m.basyuni@usu.ac.id

\begin{abstract}
The polyprenols and dolichols in mangrove litter-based salinity groups and zonations in Lubuk Kertang, North Sumatra, Indonesia, was performed using two-dimensional thin-layer chromatography. Eight sites with twenty-four samples consisting of 0 , 2 , and $3 \%$ salt concentrations and five zonations (Avicennia spp, Bruguiera spp, Nypa fruticans community, Rhizophora spp, and Sonneratia spp) were analyzed. In the zonations, two types concerning the distribution of polyprenols and dolichols were detected. Type-I, showing predominance of dolichols over polyprenols, was observed in Avicennia spp, Bruguiera spp, Nypa fruticans, and Rhizophora spp. TypeII, having both polyprenols and dolichols, was observed in Sonneratia spp. In contrast, no type-I distribution was found in the salinity group. A type-II distribution was also observed in 0,2 , and $3 \%$ salt concentrations. The diversity of polyisoprenoid composition in the mangrove litters of salinity groups was noted, whereas dolichols predominated in the zonations (80\%). In Avicennia spp litter, dolichols were found to be longer than other types of community litter (Bruguiera spp, Nypa, and Rhizophora spp). These conditions can be caused by leaf litter factors that have different ages and environments. A dendrogram was constructed using the Unweighted-Pair Group Method with Arithmetic mean (UPGMA) method to confirm these findings. The dendrogram demonstrated that the zonations and salinity groups were generally clustered according to appropriate species and families. The study suggested that dominated dolichols function as chemotaxonomic markers, useful in identifying and classifying mangroves, and in phylogenetic studies.
\end{abstract}

Keywords - Chemotaxonomic marker; phylogenetic; polyprenol reductase; rehabilitation, true mangrove.

\section{INTRODUCTION}

Mangrove forests are tropical and subtropical coastal vegetation communities dominated by several mangrove species that can grow and thrive in muddy coastal areas [1]. These vegetation communities generally grow in intertidal areas that are adequately exposed to periodic inundation and freshwater flows and are protected from large waves and strong tidal currents. Therefore, mangroves are found along the shores of shallow bays, estuaries, deltas, and protected coastal areas.

The mangrove zonation was an ecological phenomenon to the coastal waters in areas including tidal rhythms. The different tides effect allows the development of unique communities for each area [2]. Zonation studies in coastal waters have been widely carried out, although they lack in soft substrate coastal waters (sand and mud), especially in mangroves.

True mangrove forests have species that specifically grow in intertidal zones, such as Avicennia marina, Sonneratia alba, Rhizophora apiculata, Kandelia candel, Ceriops tagal, and Bruguiera gymnorrhiza [3], [4]. Different mangrove species were adopted different adaptation strategies to high salinity, it depended on their differential ability for salt toleranceMangrove species have a general characteristic for tolerating seawater with high salinity, implying the convergent adaptation of this species [5].

Several of the decomposed mangrove litter were absorbed into the mangroves, and on the other hand, it was additional organic material input for the surrounding mangrove ecosystem [6]. The accumulating organic material benefits 
were resulting from the decomposition of mangrove forest litter include the enrichment of nutrients in the ecosystem, maintenance of nursery areas and spawning grounds, and protection of various aquatic biota [7].

Five-carbon of polyisoprenoids were linear polymer units present in almost the living cells. Long chains of polyisoprenoids are found in various plant tissues [8]. There are two types of polyisoprenoids concerning the $\alpha$-isoprene structure. The first type is polyprenol, alcohol with a single, double bond in each isoprenoid unit ( $\alpha$-saturated isoprenoid alcohol), characteristic of bacterial cells and plant parts. The second type is dolichol, without double bonds in the $\mathrm{OH}-$ terminal isoprenoid unit ( $\alpha$-saturated isoprenoid alcohol). Dolichols are present mainly in animals. Using a twodimensional thin-layer chromatography method, this study aimed to identify polyprenols and dolichols in mangrove leaves and litters.

\section{A. Study Site}

The study was carried out from Lubuk Kertang mangrove forest, North Sumatra, Indonesia, covering an area of about 1200 ha. The Lubuk Kertang village is situated at 04 $07^{\prime} 39.71^{\prime \prime}$ North latitudes and 98 $30^{\prime} 97.87^{\prime \prime}$ East longitudes (Figure 1). Lubuk Kertang region belongs to Langkat Regency and Brandan Barat district. The zone was determined by identifying the communities around the location made from land to sea using a hand refractometer. The study sites consisted of the community of Rhizophora spp, Bruguiera spp, Nypa fruticans community, Sonneratia spp, and Avicennia spp, as shown in Figure 1. The salinity zone was determined by measuring the salinity level, carried out from landward to seaward using a hand refractometer. The study sites consisted of three zones: zone 1 with salinity $(0 \%)$, zone 2 with salinity ( $2 \%$ ), and zone 3 with salinity ( $3 \%$ ), as depicted in Figure 1.

\section{MATERIALS AND METHOD}

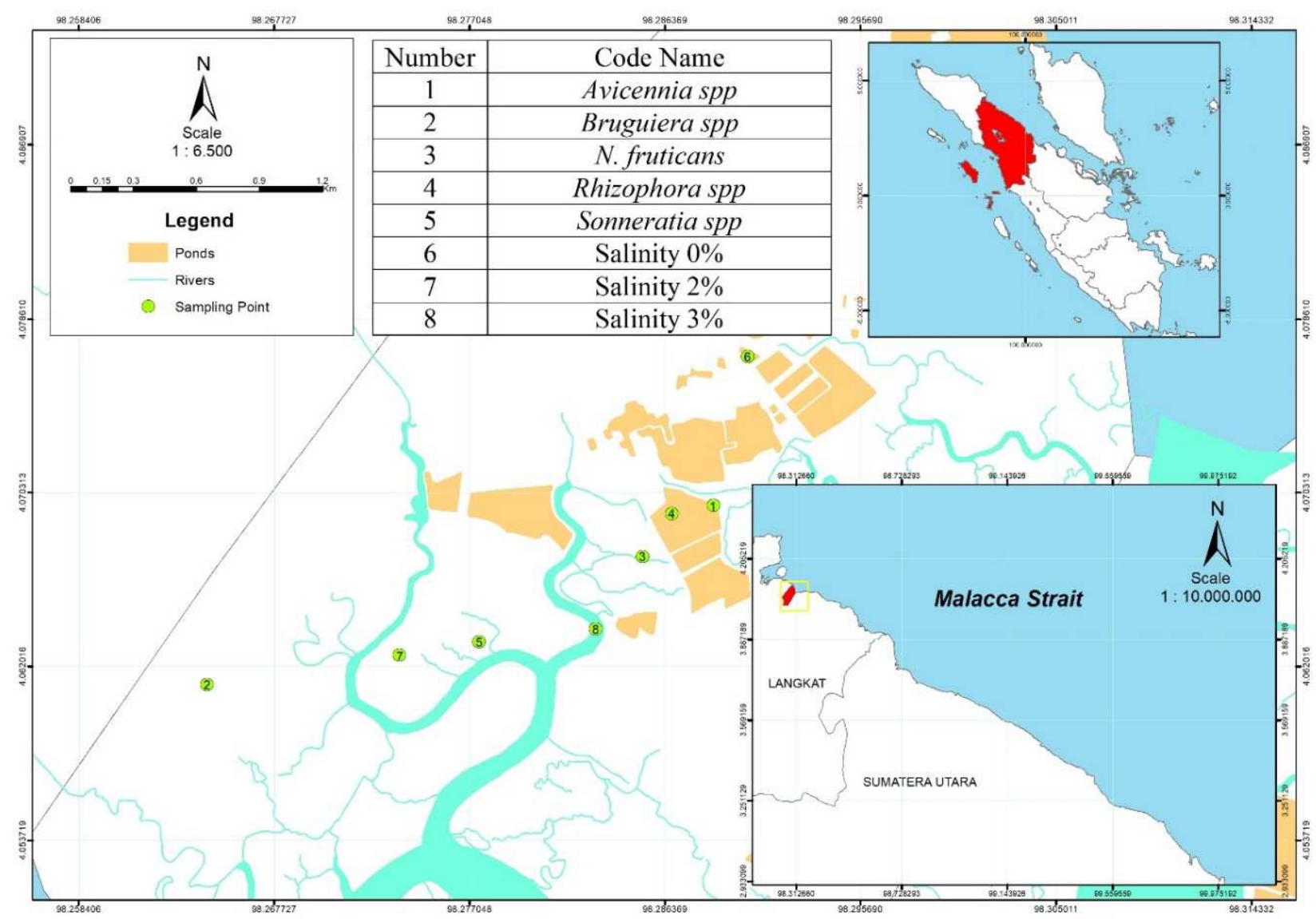

Fig. 1 Study sites showing a sampling point from mangrove litters, 1. Avicennia spp., 2. Bruguiera spp, 3. N. fruticans community, 4. Rhizophora spp, 5. Sonneratia spp, 6. Salinity $0 \%, 7$. Salinity $2 \%$, and Salinity $3 \%$.

The samples from each salinity zone were collected using clear plastic bags to not mix with the other samples. At the time of sample collection, specific criteria were observed: fallen tree leaves, fallen brown litter that was still fresh, not taken. Clear plastic bags were labeled with the names of each salinity group according to their level so that it is easy to find samples in the research process. All the mangrove litter samples were stored in an ice cupboard before use.
Then, the litter samples were collected. It was cutting for easier to dry. Furthermore, the samples were assigned in envelopes, labeled according to their respective zones or communities. In the next stage, it was ensured that the litter inside the envelope matched each type's label and then put in an oven at $60-70^{\circ} \mathrm{C}$ for $2 \times 24$ hours. Thereafter, the dry litter was used in the polyisoprenoid alcohol isolation (Fig. 2). 


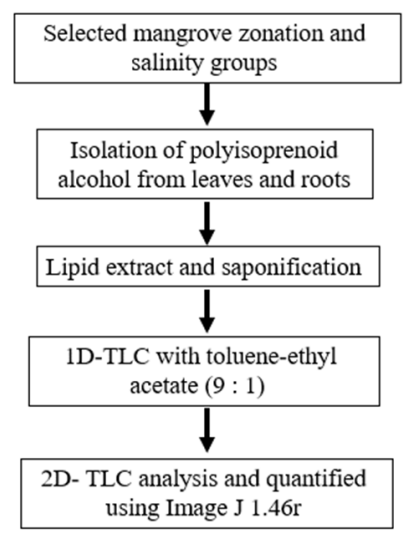

Fig. 2 Flow chart of polyisoprenoid isolation for leaves and roots.

\section{B. Chemicals}

Dolichols from pig liver was obtained from Sigma. The dolichol $\left(\mathrm{C}_{95}-\mathrm{C}_{110}\right)$ standard was from skipjack tuna livers [9]. Silica gel 60 TLC plates and reversed-phase silica RP-18 HPTLC plates were purchased from Merck. All other chemicals and solvents were of reagent grade.

\section{Isolation of Polyisoprenoid Alcohols}

The procedure for the isolation of polyisoprenoid was performed as previously described [10]. Leaves and roots were dried at $60-75{ }^{\circ} \mathrm{C}$ for $1-2$ days. The dried tissue $(5 \mathrm{~g}$ each), crushed into a fine powder, was immersed in $30 \mathrm{ml}$ solvent of chloroform/methanol ( $2: 1, \mathrm{vol} / \mathrm{vol})$ for $48 \mathrm{~h}$. The lipid extract of leaves and roots was then saponified at $65^{\circ} \mathrm{C}$ for $24 \mathrm{~h}$ in $86 \%$ ethanol containing $2 \mathrm{M} \mathrm{KOH}$. The nonsaponifiable lipid of each tissue was extracted with hexane, and the organic solvent was evaporated, thereafter redissolved in hexane.

\section{Analysis by Two-Dimensional Thin Layer Chromatography}

The first dimension TLC was carried out for $60 \mathrm{~min}$ on a silica gel glass plate $(20 \times 3 \mathrm{~cm})$ with a solvent system of toluene-ethyl acetate (9:1), as previously described [9]. The polyprenol family moved slightly faster than the corresponding dolichol family. The longitudinal edge of the first dimension TLC plate with $1 \mathrm{~cm}$ width and the concentration zone of a reversed-phase C-18 TLC was clamped, employing two magnetic bars $(4.0 \times 1.1 \times 0.8 \mathrm{~cm})$ facing each gel phase. The clamped TLC plate was developed perpendicularly to the first dimension to transfer polyprenol and dolichol into the concentration zone of the reversed-phase TLC plate. The second dimension reversed-phase C-18 silica gel TLC was performed with acetone for about $30 \mathrm{~min}$. The position of separated polyisoprenoid alcohols being developed by two-dimension silica gel TLC was identified and visualized with iodine vapor. The developed chromatographic images were subsequently obtained and digitally scanned with Canon MG6100 series printer. Polyprenols and dolichols detected on HPTLC RP-18 plates were quantified using ImageJ 1.46r [11] with dolichols and polyprenols standard as reference. The rubber-like compounds remaining on the top solvent front area of the first silica-gel plate, without having transferred onto the RP-18 plate with acetone, were detected using iodine vapor.

\section{E. Cluster Analysis}

Cluster analysis was performed on selected subsets of leaf data consisting of 75 variables from 21 species. In the analysis, eight species or communities were from this study, four species [9], and nine species [12]. All data were $\log (10)$ transformed. From these data, dendrograms representing both leaf and root data were drawn by clustering analysis using the unweighted pair group method with arithmetic mean (UPGMA) and MVSP (multivariate statistical package) 3.22 (Kovach Computing Service). Euclidean distance was chosen as the criterion for cluster combination.

\section{F. Nutrient Analysis}

Analysis for element $\mathrm{N}$ of litter samples used fresh litters. The samples were blended and heated in an oven at $70^{\circ} \mathrm{C}$, and then weighed. Subsequently, selenium solution and $5 \mathrm{ml}$ of sulfuric acid were added into a tube after it was allowed to stand for 24 hours, and then it was heated for 24 hours. The digester was blocked at a temperature of $100^{\circ} \mathrm{C}$ for 2 hours. Thereafter, $2 \mathrm{ml}$ of hydrogen peroxide was added, and it was reheated at $330^{\circ} \mathrm{C}$ for 2 hours, following which $2 \mathrm{ml}$ of hydrogen peroxide was added again. It was then cooled and filtered using a Whatman paper filter into a $50 \mathrm{ml}$ volumetric flask. The extraction results were read on the continuous flow analyzer, and the concentration of $\mathrm{N}$ was immediately read from the results.

$\mathrm{P}$ and $\mathrm{Na}$ matters were analyzed using a dry destruction analysis, a merging system that uses a muffle furnace tool. The sample was smoothed and heated in an oven at $70^{\circ} \mathrm{C}$. After drying, the sample weighing 0.5 grams was transferred into a porcelain cup and then pulverized using a muffle furnace at a temperature of $200^{\circ} \mathrm{C}$ for one hour. The temperature of the muffle furnace was then raised to $450^{\circ} \mathrm{C}$ for two hours, then $2 \mathrm{ml}$ of concentrated HCL was added to the samples. Subsequently, it was heated on a hotplate to dry, and then $2 \mathrm{ml} \mathrm{HCl}$ has added again. The extraction results were filtered using filter paper in a $50 \mathrm{ml}$ vase flask. The results can be read or obtained for $\mathrm{P}$ using a continuous flow analyzer and for element $\mathrm{Na}$, using the atomic absorption spectrophotometer (UV/Vis Spectrophotometer UV-1280, Shimadzu).

\section{G. Statistical Analysis}

The data were described as mean \pm standard deviation (SD) values for a given number of observations, $n=3$. Mean nutrient values were statistically compared among samples using one-way analysis of variance (ANOVA), followed by pairwise comparisons made using Fisher's Least Significant Difference (LSD). The value of $\mathrm{P}<0.05$ was selected as the limit of statistical significance. All statistical comparisons were calculated using the SAS 9.1 statistical software program (SAS Institute Inc., Cary, NC, USA).

\section{RESULT AND DISCUSSION}

\section{A. Polyisoprenoid Profile in Litter, Based on Community and Zonation}

The study has conducted the content and quantification of polyisoprenoid compounds from zonation and salinity groups based on mangrove litter. The mangrove litter extraction to Avicennia spp, Bruguiera spp, Nypa, Rhizophora spp, and 
Sonneratia spp communities, total lipid dolichol and polyprenol, were obtained (Table 1).

The distribution of polyprenol and dolichol with the carbon chain length in the community was described in Table 1 . The total lipids and polyprenol and dolichol content from each zonation litter were varied. The total lipids in the litter network ranged from 365.3 to 648.2 , with the smallest total lipids found in the Nypa community litter (365.3), and the largest total lipids found in the mangrove litter of the Sonneratia spp community (648.2). The most significant number of polyisoprenoids in litter tissue was Sonneratia spp $(39.03 \mathrm{mg} / \mathrm{g})$, and the smallest polyisoprenoid was found in Nypa litter (7.3 mg g).

Furthermore, the polyisoprenoid alcohols include dolichol than polyprenol. Based on the thin layer chromatography analysis results of polyisoprenoids from mangrove litter (Sonneratia spp), dolichol chains of C80-C140, C90-C125, C80-C115, C85-C115, and C80-C140 were found (Table 2). Then, the polyisoprenoid compounds were found in Sonneratia spp litter with C65-C140 length (Table 2). Interestingly, polyisoprenoid compounds were only found in Sonneratia spp litter. In Avicennia spp, Bruguiera spp, Nypa community, and Rhizophora spp, polyprenol compounds were not found; only dolichol compounds were found in this study, similar to [9]. Whereas, in A.marina, B, gymnorrhiza, and old leaves of B. gymnorrhiza, and E. agallocha; in the case of $B$. gymnorrhiza leaves, polyprenol compounds were not detected.

TABLE I

OCCURRENCE AND DisTRIBUTION OF POLYPRENYL ACETONES, POLYPRENOLS, DOLICHOLS IN MANGROVES

\begin{tabular}{|c|c|c|c|c|c|c|c|c|c|c|c|c|c|c|}
\hline \multirow[t]{2}{*}{ Species } & \multirow[t]{2}{*}{$\begin{array}{l}\text { Tissu } \\
\text { e }\end{array}$} & \multirow{2}{*}{$\begin{array}{c}\text { TL } \\
(\mathrm{mg} / \mathrm{g} \\
\mathrm{dw})\end{array}$} & \multirow{2}{*}{$\begin{array}{c}\text { PI } \\
(\mathrm{mg} / \mathrm{g} \\
\mathrm{dw}) \\
\end{array}$} & \multirow{2}{*}{$\begin{array}{c}\text { Pol } \\
\text { Ace } \\
(\mathrm{mg} / \mathrm{g})\end{array}$} & \multirow{2}{*}{$\begin{array}{c}\text { Pol } \\
(\mathrm{mg} / \mathrm{g} \\
\text { ) }\end{array}$} & \multirow{2}{*}{$\begin{array}{c}\text { Dol } \\
(\mathrm{mg} / \mathrm{g} \\
)\end{array}$} & \multicolumn{4}{|c|}{$\%$ in total lipid } & \multicolumn{3}{|c|}{$\%$ in polyisoprenoid } & \multirow[t]{2}{*}{$\begin{array}{c}\text { Typ } \\
\text { e }\end{array}$} \\
\hline & & & & & & & PI & $\begin{array}{l}\text { Pol } \\
\text { Ace } \\
\end{array}$ & $\begin{array}{c}\text { Po } \\
1\end{array}$ & Dol & $\begin{array}{l}\text { Pol } \\
\text { Ace }\end{array}$ & Pol & Dol & \\
\hline Av. Alba* & leaves & 62.1 & 5.5 & nd & nd & nd & 8.9 & nd & nd & 8.9 & nd & nd & 100 & I \\
\hline Av. Lanata* & leaves & 86.8 & 14.9 & nd & nd & nd & $\begin{array}{c}17 . \\
1\end{array}$ & nd & nd & $\begin{array}{c}17 . \\
1\end{array}$ & nd & nd & 100 & I \\
\hline A. marina\# & leaves & 108 & 3.3 & nd & 1.0 & 1.0 & 3.1 & nd & 1.0 & 3.0 & nd & 4.2 & $\begin{array}{c}95 . \\
8\end{array}$ & I \\
\hline Av. Officinalis* & leaves & 92.7 & 8.4 & nd & nd & nd & 9.1 & nd & nd & 9.1 & nd & nd & 100 & I \\
\hline Avicennia spp & litters & 365.3 & 18 & nd & nd & nd & 4.9 & nd & nd & 4.9 & nd & nd & 100 & I \\
\hline B. cylindrical* ${ }^{*}$ & leaves & 124.2 & 7.9 & nd & 3.4 & 3.4 & 6.3 & nd & 2.7 & 3.6 & nd & 2.7 & $\begin{array}{c}57 . \\
3\end{array}$ & II \\
\hline B. gymnoorhiza\# & leaves & 154 & 3.7 & nd & nd & nd & 2.4 & nd & nd & 2.4 & nd & nd & 100 & I \\
\hline B. parviflora* & leaves & 186.3 & 29.4 & nd & nd & nd & $\begin{array}{c}15 . \\
8\end{array}$ & nd & nd & $\begin{array}{c}15 . \\
8\end{array}$ & nd & nd & 100 & I \\
\hline Bruguiera spp & litters & 533.2 & 8.5 & nd & nd & nd & 1.6 & nd & nd & 1.6 & nd & nd & 100 & I \\
\hline N. fruticant* & leaves & 67.2 & 10.7 & nd & nd & nd & $\begin{array}{c}15 . \\
9\end{array}$ & nd & nd & $\begin{array}{c}15 . \\
9\end{array}$ & nd & nd & 100 & I \\
\hline $\begin{array}{l}\text { N. fruticans } \\
\text { comm }\end{array}$ & litters & 471.4 & 7.3 & nd & nd & nd & 1.5 & nd & nd & 1.5 & nd & nd & 100 & I \\
\hline R. apiculata* & leaves & 97 & 6.1 & nd & 2.6 & 2.6 & 6.3 & nd & 2.7 & 3.6 & nd & $\begin{array}{c}42 . \\
8\end{array}$ & $\begin{array}{c}57 . \\
2\end{array}$ & II \\
\hline R. mucronata* & leaves & 53.1 & 4.1 & nd & 0.4 & 0.4 & 7.7 & nd & 0.7 & 7.0 & nd & 9.8 & $\begin{array}{c}90 . \\
2\end{array}$ & I \\
\hline R. stylosa\# & leaves & 136 & 6.1 & nd & 0.4 & 0.4 & 4.5 & nd & 0.3 & 4.2 & nd & 6.3 & $\begin{array}{c}93 . \\
7\end{array}$ & I \\
\hline Rhizophora spp & litters & 477.3 & 9.5 & nd & nd & nd & 2.0 & nd & nd & 2.0 & nd & nd & 100 & I \\
\hline S. alba\# & leaves & 60 & 8.6 & nd & 5.0 & 5.0 & $\begin{array}{c}14 . \\
4\end{array}$ & nd & 8.3 & 6.1 & nd & $\begin{array}{c}57 . \\
8\end{array}$ & $\begin{array}{c}42 . \\
2\end{array}$ & II \\
\hline S. caseolaris* & leaves & 65.6 & 8.8 & 1.0 & 1.2 & 1.2 & $\begin{array}{c}13 . \\
5\end{array}$ & 1.6 & 1.9 & $\begin{array}{c}10 . \\
0\end{array}$ & 11.8 & $\begin{array}{c}13 . \\
9\end{array}$ & $\begin{array}{c}74 . \\
3\end{array}$ & $\mathrm{~V}$ \\
\hline Sonneratia spp & litters & 648.2 & 39.0 & nd & 19 & 19 & 6.0 & nd & 2.9 & 3.1 & nd & 49 & 51 & II \\
\hline $0 \%$ & litters & 822.8 & 54.2 & nd & 26.9 & 26.9 & 6.6 & nd & 3.2 & 3.4 & nd & $\begin{array}{c}49 . \\
6\end{array}$ & $\begin{array}{c}50 . \\
4\end{array}$ & II \\
\hline $2 \%$ & litters & 654.3 & 60.2 & nd & 36.2 & 36.2 & 9.1 & nd & 5.5 & 3.6 & nd & $\begin{array}{c}60 . \\
2\end{array}$ & $\begin{array}{c}39 . \\
8\end{array}$ & II \\
\hline $3 \%$ & litters & 798.4 & 38.4 & nd & 21.8 & 21.8 & 4.8 & nd & 2.7 & 2.1 & nd & $\begin{array}{c}56 . \\
9\end{array}$ & $\begin{array}{c}43 . \\
1\end{array}$ & II \\
\hline
\end{tabular}

TABLE II

CARbon Chain Lengths of Polyprenylacetone, Polyprenol, Dolichol OCCuRring in Mangrove LitTERS AND LEAVES

\begin{tabular}{|c|c|c|c|c|}
\hline Species & Tissue & Polyprenol acetone & Polyprenol & Dolichol \\
\hline Av. alba & leaves & & & 6065707580859095100 \\
\hline Av. lanata & leaves & & & 707580859095100 \\
\hline A. marina & leaves & & 707580859095100 & 65707580859095100105110115120125130 \\
\hline Av. officinalis & leaves & & 4550 & 707580859095100 \\
\hline Avicennia spp & litters & & 8085 & 80859095100105110 \\
\hline B. cylindrical & leaves & & & 758085 \\
\hline B. gymnoorhiza & leaves & & & 758085 \\
\hline B. parviflora & leaves & & & 808590 \\
\hline Bruguiera spp & litters & & & 859095100 \\
\hline N. fruticants & leaves & & & 75808590 \\
\hline
\end{tabular}




\begin{tabular}{|c|c|c|c|c|}
\hline $\begin{array}{l}\text { N. fruticans } \\
\text { comm }\end{array}$ & litters & & & 7580859095 \\
\hline R. apiculata & leaves & & 5055 & 7580859095 \\
\hline R. mucronata & leaves & & 808590 & 7580859095 \\
\hline R. stylosa & leaves & & 80859095 & 7580859095 \\
\hline Rhizophora spp & litters & & & 80859095 \\
\hline S. alba & leaves & & $\begin{array}{l}65707580859095100105110115 \\
120125130140 \text { and more }\end{array}$ & 65707580859095100105110115120125130 \\
\hline S. caseolaris & leaves & $\begin{array}{l}23283338434853 \\
58636873788388\end{array}$ & 50556075808590 & 50556065707580859095100105110115120 \\
\hline Sonneratia spp & litters & & $\begin{array}{l}65707580859095100105110115 \\
120125130140\end{array}$ & 707580859095100105110115120 \\
\hline $0 \%$ & litters & & $\begin{array}{l}80859095100105110115 \\
120125130140 \text { and more }\end{array}$ & $\begin{array}{l}80859095100105110115120 \\
125130140 \text { and more }\end{array}$ \\
\hline $2 \%$ & litters & & 606570758085 & 606570758085 \\
\hline $3 \%$ & litters & & $120 \quad 707580859095100105110115$ & 707580859095100105110115120 \\
\hline
\end{tabular}

In Avicennia spp litters, the compound chains in dolichol were found highest than in other types of community litter (Bruguiera spp, Nypa, and Rhizophora spp). In contrast, the length of dolichol Nypa and Bruguiera spp had the same length of dolichol (C80-C115), but dolichol carbon chains identified in leaves showed slightly different results, possibly caused by leaf litter factors concerning different ages and environments.

\section{B. Polyisoprenoid Profile of Litter based on salinity}

The distribution of polyprenol and dolichol with carbon chain lengths of each family is presented in Table 1 . Table 1 shows the total lipids and values of polyprenol and dolichol from each leaf litter network. Total lipids are expressed as gravimetric estimates of lipid fractions. Based on Table 1, total lipids in leaf litter tissue ranged from 654.36 to 822.83 $\mathrm{mg} / \mathrm{g} \mathrm{dw}$, with the smallest total lipids being in the salinity group of $2 \%(654.36 \mathrm{mg} / \mathrm{g})$ and the largest in $0 \%$ salinity $(822.83 \mathrm{mg} / \mathrm{g})$. The was an enormous amount of polyisoprenoid in leaf litter tissue at $2 \%$ salinity (60.24), while the smallest polyisoprenoid value was found in leaf litter tissue at 3\% salinity (38.40).

Table 2 was described the distribution of polyprenol and dolichol in each leaf litter from three types of salinity variation: $0 \%, 2 \%$, and $3 \%$. Not only polyprenol but also dolichol was identified in all leaf litter tissue. No compound was detected. Further, polyprenol and dolichol compounds were found with the smallest number of chains C60-C85 at $2 \%$ salinity and the largest number of chains, $\mathrm{C} 80-\mathrm{C} 140$ at $0 \%$ salinity.

\section{The Analytical Occurrence of Polyisoprenoids and Carbon-Chain Length}

Long polyisoprenoid chains from these three salinity variations were identified using the thin layer chromatography analysis method. In leaf litter, the tissue has dominated the polyprenol and dolichol. Figure 3 showed polyisoprenoid compounds at $0 \%, 2 \%$, and $3 \%$ salinity, dominated polyprenol with the length of each carbon chain.

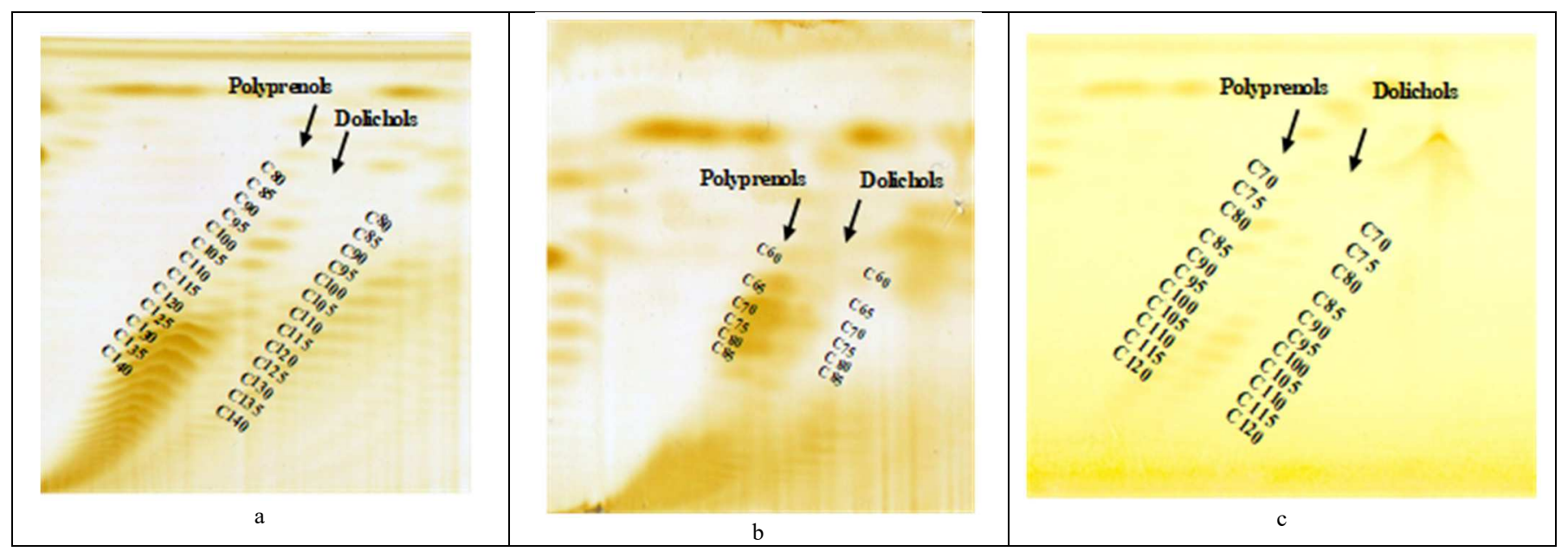

Fig. 3 Two-plate TLC of polyisoprenoids from mangrove community and zonation litters of salinity $0 \%$ (a), salinity $2 \%$ (b), and salinity $3 \%$ (c).

Using the same method for polyisoprenoid compounds from salinity variations of $0 \%, 2 \%$, and $3 \%$, dolichol was found with the length of each carbon chain length C80-C140, C60-C85, C70-C120. The litter zonation of mangroves contained the same polyprenol and dolichol chains, with the largest chains at $0 \%$ salinity range $(\mathrm{C} 80-\mathrm{C} 140)$ and the smallest chains at $2 \%$ salinity range $(\mathrm{C} 60-\mathrm{C} 85)$. In the thinlayer chromatogram of dolichol mixtures from pigs' livers, both prenols contained two internal trans double bonds. However, it was found that concerning one isoprene ratio, with longer chain length by one unit isoprene, also showing separation concerning dolichol stereochemistry [10].

Avicennia spp, Bruguiera spp, Nypa, and Rhizophora spp litter go in the I-edge, while Sonneratia spp belonging to type- 
II, can be seen in Avicennia spp, Bruguiera spp, Nypa, and Rhizophora spp litter. In contrast, Sonneratia spp is included in type-II, which can be seen in litter Avicennia spp, Bruguiera spp, Nypa, and Rhizophora spp. However, in Sonneratia spp litter, two dolichol and polyprenol cmpounds were included in type-II, because in the sample, only $48.8 \%$

A

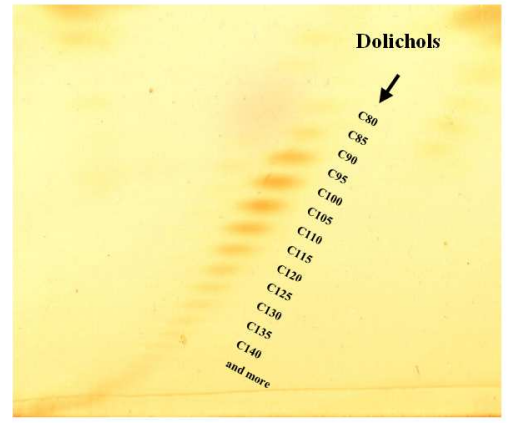

D

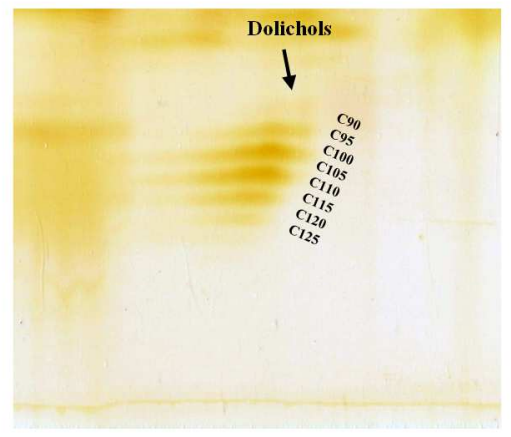

polyprenol was found. The distribution of polyisoprenoid in this study was dominated by dolichol. This type-I distributes in mangrove fault networks based on community. The analysis of polyisoprenoid in mangrove plant leaves shows that the main component of polyisoprenoid is not polyprenol compound but dolichol (Figure 4).
C

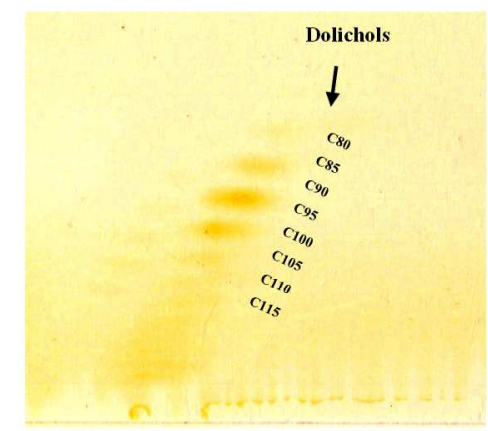

$\mathbf{E}$
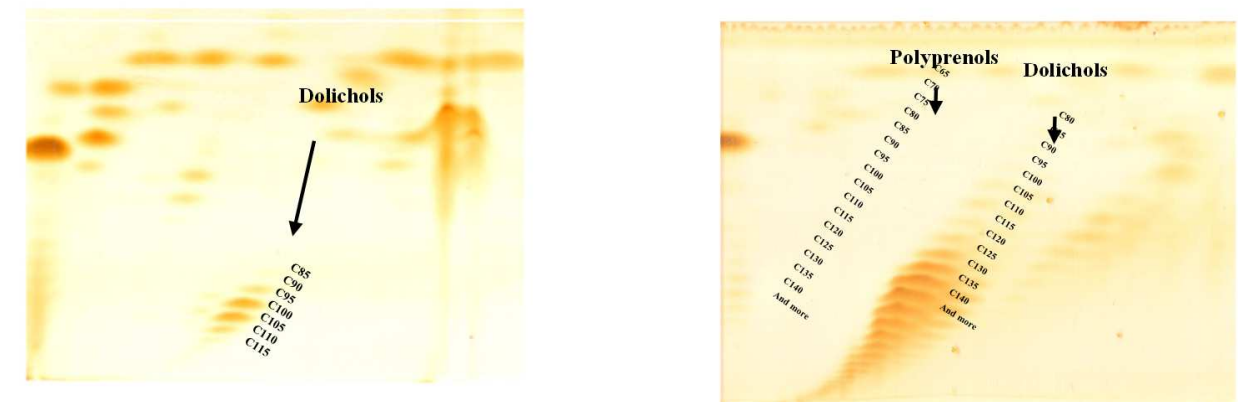

Fig. 4 Two-plate TLC of polyisoprenoids from mangrove community and zonation litters of Avicennia spp (A), Bruguiera spp (B), Nypa fruticans community (C), dan Rhizophora spp (D), dan Sonneratia spp (E).

\section{Cluster Analysis}

Cluster analysis for polyisoprenoids using data on carbonchain lengthwas used to construct separate species relationships. Figure 5 depicts the species relationships based on leaf polyisoprenoid carbon-chain lengths from 24 mangrove species. A cluster was constructed using the UPGMA method to confirm these findings. Figure 4 reveals that 21 mangrove species fell into three groups. The dendrogram demonstrated that the zonations and salinity groups were generally clustered to appropriate species and families. The cluster also suggested that polyprenol and dolichol play a role as chemotaxonomic markers, are useful to identify and classify mangrove species, and phylogenetic works. 


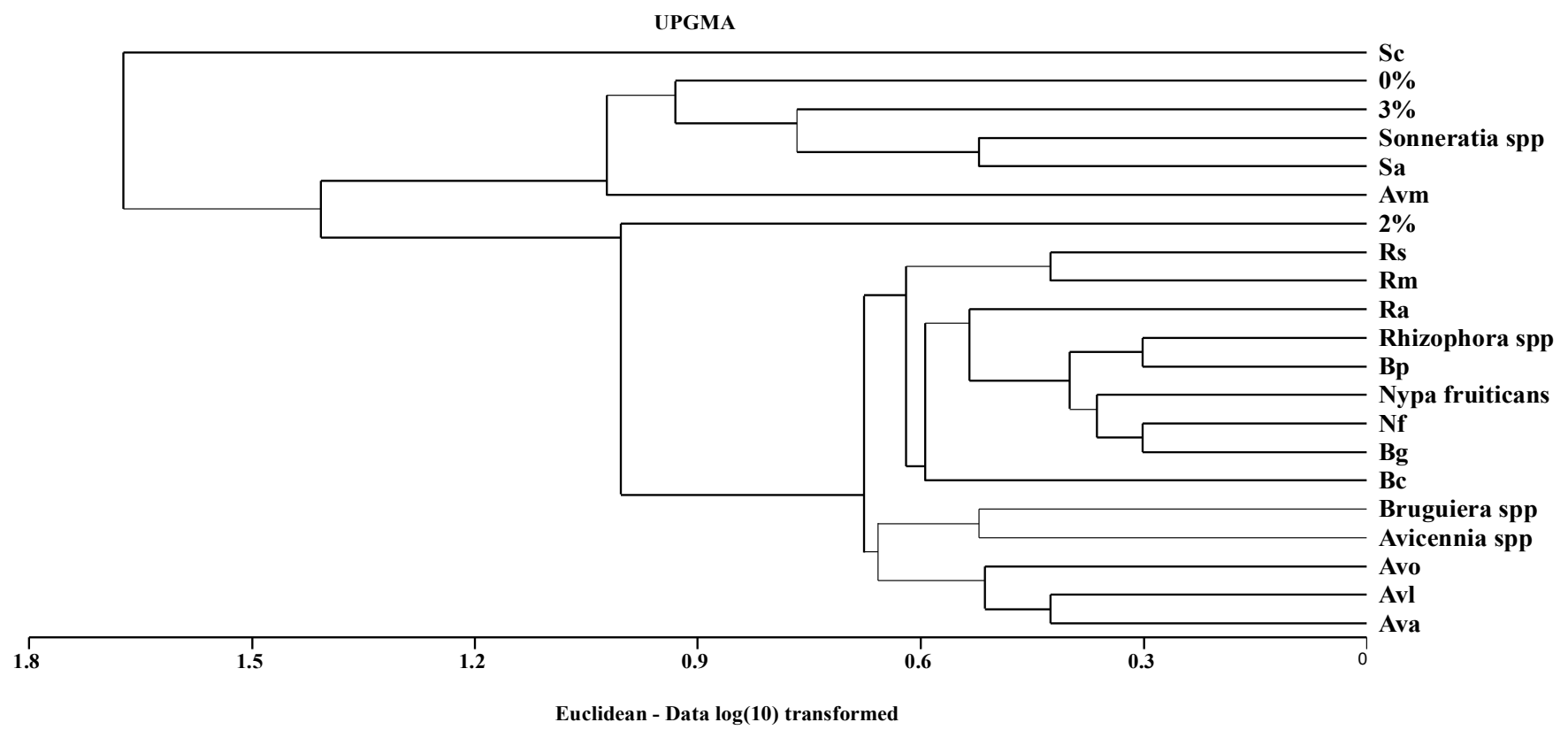

Fig. 5 Dendrogram depicting the relationship among 21 mangrove species from litter and leaf data on the carbon-chain lengths of polyisoprenoids by log (10) transformation using Euclidean distance. For species name, Ava, A. alba; Avl, A. lanata; Avm, A. marina; Avo, A. officinalis; Bg, B. gymnorrhiza; Bc, B. cylindrica; Bp, B. parviflora; Nf, N. fruticans; Ra, R. apiculata; Rm, R. mucronata; Rs, R. stylosa; and Sa, S. alba; Sc, S. caseolaris; $0 \%$, salinity $0 \% ; 2 \%$, salinity $2 \%$; and $3 \%$, salinity $3 \%$.

\section{E. Nutrient N, P, and Na in Mangrove Litters}

Table 3 was showed the content of $\mathrm{N}, \mathrm{P}$, and $\mathrm{Na}$ in mangrove litter based on community and zonation Avicennia spp, Bruguiera spp, Nypa, and Rhizophora spp, and Sonneratia spp between $0.375 \%$ and $1.789 \%$ have the highest $\mathrm{N}$ element content with $1.789 \%$ in the Avicennia spp community and that of Sonniratia spp. The smallest content was in Bruguiera spp with $0.375 \%$, and for the nutrient $\mathrm{P}$, obtained in large quantities (macronutrients), the number of nutrients (phosphorus) in plants was smaller than nutrient nitrogen, which improves plant growth and protein, whereas $\mathrm{N}$ compounds in the soil, that the plants were green. The nutrients of $\mathrm{P}$ (phosphorus) ranging from $0.006 \%$ to $0.157 \%$ was analyzed in this study based on the mangrove community, with the most nutrients in Avicennia spp and the least in Rhizophora spp.

TABLE III

NUTRIENT ANALYSIS FROM MANGROVE SALINITY CONCENTRATION

\begin{tabular}{lccc}
\hline \multicolumn{1}{c}{ Mangrove zonation litters } & $\mathbf{N}$ & $\mathbf{P}$ & Na \\
\hline Avicennia spp & $1.80 \pm 003^{\mathrm{a}}$ & $0.16 \pm 0.00^{\mathrm{a}}$ & $2.75 \pm 0.02^{\mathrm{b}}$ \\
Bruguiera spp & $0.38 \pm 0.00^{\mathrm{e}}$ & $0.04 \pm 0.00^{\mathrm{d}}$ & $1.60 \pm 0.14_{\mathrm{d}}$ \\
Nypa fruticans comm & $1.27 \pm 0.02^{\mathrm{b}}$ & $0.07 \pm 0.00^{\mathrm{c}}$ & $0.87 \pm 0.01^{\mathrm{e}}$ \\
Rhizophora spp & $0.44 \pm 0.00^{\mathrm{d}}$ & $0.01 \pm 0.00^{\mathrm{d}}$ & $2.57 \pm 0.07^{\mathrm{c}}$ \\
Sonneratia spp & $1.09 \pm 0.11^{\mathrm{c}}$ & $0.13 \pm 0.00^{\mathrm{b}}$ & $3.20 \pm 0.12^{\mathrm{a}}$ \\
\hline
\end{tabular}

Data are expressed as mean \pm SD $(n=3)$. Means with the same superscript are not significantly different each other $(\mathrm{P}<0.05)$ using Fisher's LSD.

The litters were provided for nutrients that directly or indirectly contribute to the growth of mangrove forests. The decomposition of organic matter derived from plant residues has the quality to release nutrients into the liquid. The need for nutrient concentrations is based on salinity levels, salinity of litter was various: $0 \%, 2 \%$, and $3 \%$, based on table 3 . The results depict nutrient concentrations with the highest $\mathrm{N}$ values at $2 \%$ salinity $(1.190 \mathrm{mg} / \mathrm{g})$ and the lowest value at $3 \%$ salinity $(0.524 \mathrm{mg} / \mathrm{g})$. For nutrient concentrations of the element $\mathrm{P}$, the highest value was obtained at $0 \%$ salinity with a magnitude of value 0106 and the lowest value was obtained with a value of 0.017 at salinity $3 \%$. In addition, the concentration of $\mathrm{Na}$ nutrients obtained the highest results at $3 \%$ salinity with a value of 3,382 and the lowest value obtained at salinity $0 \%$ with a value of 0.165 (Table 4 ).

TABLE VI

NUTRIENT ANALYSIS FROM MANGROVE SALINITY CONCENTRATION

\begin{tabular}{cccc}
\hline Mangrove litter & $\mathbf{N}$ & $\mathbf{P}$ & $\mathbf{N a}$ \\
\hline $0 \%$ salinity & $1.10 \pm 0.00^{\mathrm{b}}$ & $0.11 \pm 0.00^{\mathrm{a}}$ & $0.17 \pm 0.00^{\mathrm{c}}$ \\
$2 \%$ salinity & $1.19 \pm 0.01^{\mathrm{a}}$ & $0.09 \pm 0.00^{\mathrm{b}}$ & $1.87 \pm 0.42^{\mathrm{b}}$ \\
$3 \%$ salinity & $0.52 \pm 0.00^{\mathrm{c}}$ & $0.02 \pm 0.00^{\mathrm{c}}$ & $3.38 \pm 0.34^{\mathrm{a}}$ \\
\hline Means with the same superscript are not &
\end{tabular}

Means with the same superscript are not significantly different for each other $(\mathrm{P}<0.05)$ using Fisher's LSD.

Polyprenol and dolichol is divided in leaves into three types (I, II, III) [8], [9]. In Type-I, dolichol was dominated by more than $90 \%$. Type-II contained both polyprenol and dolichol compounds in plant tissues. While in Type-III, polyprenol dominated dolichol by more than $90 \%$. In mangrove leaf litter tissue, it was found to be divided into type-I and type-II. This previous study is consistent with the results obtained in this study. Only type-I and type-IIhave dolichol more abundant than polyprenol, similar to previous research that found similar results in mangrove vegetation in Okinawa [9].

The polyprenol have been reported for the total content of mangrove leaf litter at a salinity of $0 \%, 2 \%$, and $3 \%$ [13]. Therefore, this study clearly evaluates the quantification method used to calculate the total polyprenol and dolichol content with the smallest carbon chain length chains, namely $\mathrm{C} 60, \mathrm{C} 65, \mathrm{C} 70, \mathrm{C} 75$, and $\mathrm{C} 80$ at 2\% salinity, and the largest number of chains, namely C80, C85, C90, C95, C100, C105, $\mathrm{C} 110, \mathrm{C} 115, \mathrm{C} 120, \mathrm{C} 125, \mathrm{C} 120, \mathrm{C} 135$, and C140. Thus, this method can be used for the quantification of polyprenol and dolichol from other species.

Polyisoprenoid alcohol content is significantly increased in tissues during life. Moreover, the accumulation of polyisoprenoid alcohol, stimulated in leaf litter, has been 
shown to significantly induce the accumulation of polyprenol in infected leaves and leaf litter above. Interestingly, polyisoprenoid content increases exclusively in resistant tissue but not in susceptible plants [14].

In the long chain, dolichol has a variation in each dolichol network, which is different in each type, with the longest found in Avicennia spp. The shortest carbon chain was observed in Nypa and Rhizophora spp, possibly caused by adaptation and environmental factors of each community; this finding is also supported by several previous studies on dolichol that dominates at the root of R. Stylosa and S. alba, showing dolichol is dominant. However, this study is slightly different from the earlier findings of polyisoprenoid analysis in the plant world (especially leaf tissue); polyprenols are usually detected in sufficient concentrations compared to dolichol [8], [13]-[15].

Conversely, in the animal world (e.g., especially liver tissue), dolichol is the main polyisoprenoid, and only a few polyprenol family compounds are found [16]-[18]. This is due to dolichol's function as a sugar-carrying lipid in the biosynthesis of N-glycoprotein and Protein GPI. This finding makes the present research different from the previous reports that polyprenol, which dominates in mangrove plants, has a higher dolichol concentration than polyprenol compounds.

Nutrient of $\mathrm{Na}$ was playing a role in opening the stomata and can replace the role of the element $\mathrm{K}$; it can also play a role in forming tubers and preventing rot in the roots' middle part (heart rot). Hence, the role of $\mathrm{Na}$ in this study is greater than the nutrients N, P. However, the results of the analysis show no trends that appear in the levels of $\mathrm{Na} \mathrm{N}$, and $\mathrm{P}$, but the levels of soil nutrients and plant leaves are interconnected; more than two-thirds of nutrients in the soil are absorbed by plant roots and stored in leaves [19], [20].

\section{CONCLUSIONS}

This study confirmed two types associated with the distribution of polyprenol and dolichol. Type-I, it was observed in Avicennia spp, Bruguiera spp, Nypa fruticans, and Rhizophora spp. Furthermore, type-II, including in Sonneratia spp. The zonations and salinity groups were generally clustered with regard to appropriate species and family. Domination of dolichol compounds in the mangrove litters (type-I) function as chemotaxonomic markers, could be useful in identifying and classifying mangrove species and phylogenetic studies.

\section{NOMENCLATURE}

Two-Dimensional Thin Layer Chromatography

2D-TLC Unweighted-Pair Group Method with Arithmetic mean UPGMA Multivariate Statistical Package

MVSP

Total Lipid

Polyprenol

TL

Dolichol

Pol

Dol

\section{ACKNOWLEDGMENT}

This work was supported by the Directorate General of Research and Community Service, the Ministry of Research, and Technology/National Agency for Research and Innovation of the Republic of Indonesia through World-Class Research Program 2020

(No.
214/SP2H/AMD/LT/DRPM/2020). We are grateful to the Directorate of Resources, Directorate General of Higher Education, Ministry of Education and Culture, the Republic of Indonesia through World Class Professor Scheme B 2020 (No. 101.19/E4.3/KU/2020). We are obliged to Research Grant from The Indonesian Science Fund and Indonesia Endowment Fund for Education (DIPI/LPDP-RCUK Joint Call) (Grant Number N0. NE/PO14127.1).

\section{REFERENCES}

[1] Tomlinson, P.B. "The Botany of Mangroves, first ed". Cambridge University Press. London. 2016.

[2] D. R. Vaughn, T. S. Bianchi, M. R. Shields, W. F. Kenney, and T.Z. Osborne. "Increased organic carbon burial in northern Florida mangrove-salt marsh transition zones". Global Biogeochem. Cy., vol. 34 pp. 5, 2020, doi:10.1029/2019gb006334

[3] S. Sreelekshmi, C. M. Preethy, R. Varghese, P. Joseph, C.V. Asha, S. B. Nandan, and C. K. Radhakrishnan. "Diversity, stand structure, and zonation pattern of mangroves in southwest coast of India". J. Asia Pac. Biodivers., vol. 11(4), pp. 573-582, 2018, doi:10.1016/j.japb.2018.08.001

[4] M. Basyuni, A. Hayullah, M. Hamka, L. A. Putri, and S. Baba. "Growth of salt-secretor and non-salt secretor mangrove seedlings with varying salinity and their relations to habitat zonation". IOP Conf. Ser.: Earth Environment Sci., vol. 236, pp. 012050, 2019, doi:10.1088/1755-1315/236/1/012050

[5] A. I. Inyang and Y. S. Wang. "Phytoplankton diversity and community responses to physicochemical variables in mangrove zones of Guangzhou Province, China". Ecotoxicology, vol. 29, pp. 650-668, 2020, doi:10.1007/s10646-020-02209-0.

[6] T. L. Nham-Tran, A. F. Miranda, A. Gupta, M. Puri, A. S. Ball, B. Adhikari, and A. Mouradov. The nutritional and pharmacological potential of new Australian thraustochytrids isolated from mangrove sediments. Mar. Drugs, vol. 18, pp. 151, 2020, doi: $10.3390 / \mathrm{md} 18030151$

[7] E. Swiezewska and W. Danikiewicz. "Polyisoprenoids: Structure, biosynthesis and function". Prog. Lipid Res., vol. 44, pp. 235-258, 2005, doi:10.1016/j.plipres.2005.05.002.

[8] M. Basyuni, M. Wasilah, P. A. Z. Hasibuan, N. Sulistiyono, Sumardi Y. Bimantara, R. Hayati, H. Sagami, and H. Oku. "Salinity and subsequent freshwater influences on the growth, biomass and polyisoprenoids distribution of Rhizophora apiculata seedlings". Biodiversitas, vol. 20, pp. 388-395, 2019 , doi:10.13057/biodiv/d200146.

[9] M. Basyuni, H. Sagami, S. Baba, H. Iwasaki, and H. Oku. "Diversity of polyisoprenoids in ten Okinawan mangroves". Dendrobiology, vol. 75, pp. 167-175, 2016. doi: 10.12657/denbio.075.016.

[10] T. Qurrohman, M. Basyuni, and P. A. Z. Hasibuan. "Polyisoprenoids from Avicennia marina induces on P13k, Akt1, mammalian target of rapamycin, Egfr, and P53 gene expression using reverse transcriptionpolymerase chain reaction". Open Access Maced. J. Med. Sci., vol. 8, pp. 146-152, 2020, doi:10.3889/oamjms.2020.3328.

[11] C. T. Rueden, J. Schindelin, M. C. Hiner, B. E. DeZonia, A. E. Walter, E. T. Arena, and K. W. Eliceiri. "ImageJ2: ImageJ for the next generation of scientific image data". BMC bioinformatics, vol. 18, no. 1, pp. 1-26, 2017, doi:10.1186/s12859-017-1934-z

[12] M. Basyuni, H. Sagami, S. Baba, and H. Oku. "Distribution, occurrence, and cluster analysis of new polyprenyl acetones and other polyisoprenoids from North Sumatran mangroves". Dendrobiology, vol. 78 , pp. 18-31, 2017, doi:10.12657/denbio.078.003.

[13] N. L. Dahibhate, D. Kumar, and K. Kumar. "Determination of bioactive polyphenols in mangrove species and their in-vitro antiCandida activities by ultra-high-performance liquid chromatographyelectrospray ionization-tandem mass spectrometry (UPLC-ESIMS/MS)". Anal. Lett., vol. 54 (4), pp. 608-624., 2021. doi:10.1080/00032719.2020.1774600.

[14] S. Yamashita and S. Takahashi. "Molecular mechanisms of natural rubber biosynthesis". Ann. Rev. Biochem., vol. 89, 821-851, 2021. Yamashita, S., \& Takahashi, S. (2020). Molecular Mechanisms of Natural Rubber Biosynthesis. Annual Review of Biochemistry, 89(1), doi:10.1146/annurev-biochem-013118-111107.

[15] J. H. Medina-Calderón, J. E. Mancera-Pineda, E. Castañeda-Moya, and V. H. Rivera-Monroy. "Hydroperiod and Salinity Interactions Control Mangrove Root Dynamics in a Karstic Oceanic Island in the 
Caribbean Sea (San Andres, Colombia)". Front. Mar. Sci., vol. 7, 1194, 2021, doi.org/10.3389/fmars.2020.598132.

[16] K. Van Gelder, L. K. Virta, J. Easlick, N. Prudhomme, J. A. McAlister, J. Geddes-McAlister, and T. A. A. Akhtar "Central role for polyprenol reductase in plant dolichol biosynthesis". Plant Sci., vol. 303, 110773, 2021, doi:10.1016/j.plantsci.2020.110773.

[17] D. E. Long, A. G. Villasante Tezanos, J. N. Wise, P. A. Kern, M. M. Bamman, C. A. Peterson, and R. A. A. Dennis "Guide for using NIH Image $\mathrm{J}$ for single slice cross-sectional area and composition analysis of the thigh from computed tomography". PloS One, vol. 14(2), pp. e0211629, 2019, doi:10.1371/journal.pone.0211629.
[18] H. Sagami, E. Swiezewska, and Y. Shidoji. "The history and recent advances in research of polyprenol and its derivatives". Biosci. Biotechnol. Biochem., vol. 82, pp. 947-955, 2018, doi:10.1080/09168451.2017.1411775.

[19] J. Wang, Y. Xu, and G. Wu. "The integration of species information and soil properties for hyperspectral estimation of leaf biochemical parameters in mangrove forest". Ecol. Indic., vol. 115, pp. 106467, 2020, doi:10.1016/j.ecolind.2020.106467.

[20] M. F. Adame, R. Reef, N. S. Santini, E. Najera, M. P. Turschwell, M. A. Hayes, and C. E. Lovelock. "Mangroves in arid regions: Ecology, threats, and opportunities". Estuar. Coast. Shelf Sci.,vol. 248, pp. 106796, 2021, doi:10.1016/j.ecss.2020.106796 . 